\title{
Inbalt des I. Bandes (2. Teil)
}

Gekreutzigte Liebsflammen (Titelblatt) . . . . . . 1

Gekreutzigte Liebsflammen (Titelkupfer) . . . . . . 2

Gekreutzigte Liebsflammen (faksimiliertes Titelblatt). 3

Gekreutzigte Liebsflammen . . . . . . . . . . . . . 4

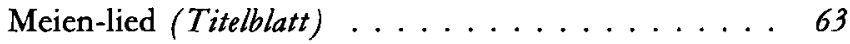

Meien-lied (faksimiliertes Titelblatt) $\ldots \ldots \ldots \ldots 65$

Meien-lied . . . . . . . . . . . . . . 6 67

Gúldener Regen (Titelblatt) $\ldots \ldots \ldots \ldots \ldots .71$

Gúldener Regen (faksimiliertes Titelblatt) . . . . . . 73

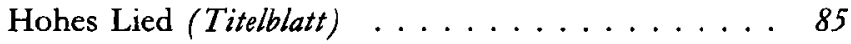

Hohes Lied (Abbildung) $\ldots \ldots \ldots \ldots \ldots \ldots . . \ldots$

Hohes Lied (Titelkupfer) _. . . . . . . . . . 87

Hohes Lied (faksimiliertes Titelblatt) _. . . . . . 89

Hohes Lied . . . . . . . . . . . . . . . . . 90

Geistliche Seelen-Lust (Titelblatt) . . . . . . . . 195

Geistliche Seelen-Lust . . . . . . . . . . . . . 196

Schơne Hamburgerin (Titelblatt) . . . . . . . . 223

Schóne Hamburgerin (faksimiliertes Titelblatt) _. . 225

Schóne Hamburgerin . . . . . . . . . . . . . . 227

Die Reinweisse Herzogin (Titelblatt) . . . . . . . 259

Die Reinweisse Herzogin (faksimiliertes Titelblatt) . . 261

Die Reinweisse Herzogin . . . . . . . . . . . . 263

Lehr=Gesånge (Titelblatt) . . . . . . . . . . 283

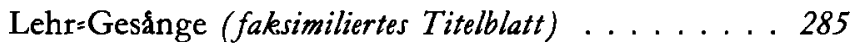

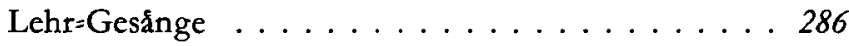


Haupt='Tugenden Dreiling (Titelblatt) . . . . . . . 357

Haupt=Tugenden Dreiling (faksimiliertes Titelblatt) . . 359 Haupt=Tugenden Dreiling . . . . . . . . . . 361

Variantenverzeichnis . . . . . . . . . . . . 369 Nacbwort des Herausgebers . . . . . . . . . . . . 386 